\title{
The Pictures in Enhancing Students English Learning
}

\section{Penggunaan Metode Gambar dalam Meningkatkan Pembelajaran Bahasa Inggris}

\author{
Susanti \\ STMIK Pontianak, Jl.Merdeka Barat, No.372 \\ Program Studi Sistem Informasi, STMIK Pontianak, Pontianak \\ E-mail Address: santy.mayfoura@gmail.com
}

\begin{abstract}
Writing is one of the four language learning skills which must be well-educated by the language learners. And it is as the most difficult skill to be executed which comes across by the students of the Vocational School of SMKN 4 Pontianak. The writing obstacles such as they do not know what should be written, what topics to be described, limited vocabularies, incorrectly grammar, and the coherency. Educators are desired to lend a hand the students with their learning complication, especially their writing skill. The Picture-Cued Technique is the practice to be carried out to the workshop of Community Engagement at the Vocational School of SMKN 4, which located on Komodor Yos Soedarso Street, Pontianak, Kalimantan Barat. The aim of this community engagement workshop to familiarize and to assist the learners of the Vocational School of SMKN 4 Pontianak with the procedure of the Picture-Cued Technique to facilitate their writing hindrances. The students of the Vocational School of SMKN 4, eleventh grade, consisted of 32 students who become the participants in this community engagement study. The outcome of this community engagement is students are familiarized to the Picture-Cued Practice then assist them in overcoming writing hindrances in learning writing competence.

Keywords - to familiarize, to boost, the vocational school of SMKN 4, community services workshop, picture-cued technique

Abstrak

Menulis merupakan satu dari empat keterampilan berbahasa yang harus benar-benar dipelajari oleh pelajar. Dan menulis merupakan keterampilan bahasa yang tersulit dalam penerapannya yang dihadapi siswa SMKN 4 Pontianak. Permasalahan dalam menulis sepertmereka tidak tahu apa yang seharusnya ditulis, topik apa yang akan dikemukakan, keterbatasan kosakata, tata bahasa yang salah, dan koherensi. Pendidik berkeinginan untuk membantu siswa dengan permasalahan pembelajaran, khususnya keterampilan menulis mereka.Teknik Picture-cued adalah metode yang diterapkan pada workshop pengabdian kepada masyarakat pada sekolah kejuruan SMKN 4 yang berlokasi di jalan Komyos sordarso, Kalimantan Barat. Tujuan dari workshop pengabdian kepada masyarakat ini untuk memperkenalkan dan membantu siswa-siswi SMKN 4 Pontianak dengan langkah-langkah teknik picture-cued untuk memfasilitasi mereka dalam mengatasi permasalahan dalam menulis. Siswa SMKN 4 Pontianak kelas X1, terdiri dari 32 siswa yang menjadi peserta dalam workshop PKM ini. Tujuan dari PKM ini adalah untuk memperkenalkan teknik picture-cued dan membantu siswa dalam mengatasi permasalah dalam menulis untuk kemampuan menulis.
\end{abstract}

Kata Kunci- untuk memperkenalkan, untuk meningkatkan, sekolah kejuruan SMKN 4, PKM, teknik gambar

\section{INTRODUCTION}

English is one of the compulsory subjects to be taught at school especially at the vocational school of SMKN 4 Pontianak. English is familiarized to learners since they were still 
at elementary schools. So it means they had learned English for more than 10 years. But English is still as foreign language for us and many Indonesians still cannot communicate in English. Why? This is still a question to be explored by us, as the educational practitioners. There are four skills must be learned and conquered by learners in learning English, those are reading, listening, speaking, and writing. Reading and listening are as passive skills then, speaking and writing are included as productive skills. In this Community Engagement Workshop writing becomes the skills to be discussed and the technique utilized in assisting learners writing obstacles come across in learning.

As productive skills, writing conveys information to others to be read. Thus the writing result must be interesting, easily understood, the use of proper vocabulary, proper use of tenses, and the coherency. It means before starting writing we must have previous knowledge as a basic knowledge. What already mentioned before are the obstacles come across by learners of SMKN 4 Pontianak, those are topics to be written, the vocabularies used, tenses used, and the coherency. Writing is integrated with other skills and cannot be separated, thus all become the basic knowledge before writing. Students of SMKN 4 come across obstacles in writing, they find it difficult to find what ideas must be written, that is why they looked confused what should be written, as consequences they wrote nothing. There are many reasons why writing is considered difficult skill to be learned by learners. Students' writing ability was still poor was a study conducted by Haryani (1990:2), then they had very bad occurrences in arranging sentences in logical order and in good paragraph formation [1]. It is a proficiency to prompt their thoughts in written, which involves complicated series of actions. Writing comprises multifaceted practices like producing a detailed concern or reaction, collection, screenplay, maturity which cause it hard to be conquered [2]. Richards and Renandya (2002: 22) cited that writing is the most thorny and complex skills for learners to master since in generating a wellmannered sentence some parts have to be considered by learners. The 5 main parts of writing, namely: language utility, mechanical skill, content, stylistic skills, and judgement skills [3]. Writing is a communicative act, a way of sharing observation, information, thoughts, or ideas with ourselves and others (Cohen and Reil, 1989:2) [1].

Writing is usually directed to others for a specific purpose. It is an active skill that demands learners to be lively in creating language moreover it is supposed to be a disputing chores since it demands critical thingking for rising and conveying thoughts precisely [3]. Can not be denied writing is essential and frequently expended by people's daily routinities life as writing messages, report also the research dessemination'outcomes or in office issues. According to Text-Oriented Approach writing capacity is regarded as the competence to generate "acontextually" the right pattern of language; following demanded forms in each sentence. Meanwhile, on Process/Cognitive Approach it focuses on the writer does while the writing process running, it defines as to introduce and develop thoughts with revising also editting attempts for the reliability texts [4]. In addition, clarified by Hogue, "Writing is a process of creating, organizing, writing, and polishing". Align with this, Rohmah cited that writing contain the complete control of whole factors in the target language such as grammar, content, vocabulary, spelling, and mechanics together [2].

Picture-Cued technique is the writing technique to be implemented in this activity done at SMKN 4 on Thursday $15^{\text {th }}$ February 2020 in a community engagement workshop. The aim of this community service workshop is to assist learners in overcoming their writing obstacles using Picture-Cued technique. Picture-Cued is a teaching technique which applying pictures in writing activity, it contains pictures telling or illustrating someone, something or somewhere. It may guide and generate ideas [5]. By looking at the pictures it may arouse students' imagination to the pictures seen then have ideas to be written [5]. Aligned with this Wright (1989) attaches that pictures offer involvement to learners' curiosity and motivation, impression of language in context, also arouse learners' concepts. The positions of pictures as productive skill (speaking and writing) are (1) Pictures may derive learners' motivation and thought and cause them involve in learning; (2) Pictures may initiate contextualized language learning motion; (3) Pictures may nurture clarification objectively and subjectively; (4) Pictures may indicate to 
questions' reaction, or as well-ordered practices; (5) Pictures can promote and pass information in intensity with conversation, storytelling, and discussion [6]. Besides, Yunus (1981: 49) testifies more that picture sequence in picture-cued practice contains a story or event sequence to assist learners to create and expand their thoughts, also help them to categorize their composing and to know the steps and the order. Moreover help them to construct their mind and assimilate their paragraph for a logical and well-ordered script [6].

Brown (2004), the picture-cued technique can be counted an essential and influential method to provoke learners' spoken language competence at extensive and intensive rank. Besides, pictures are counted a pictorial media deliver appropriate information. Likewise, it may boost learners engagement and initiate positive manner towards English, and offer motivation and non-verbal incentive that make leaners grasp well [7]. In addition, Wright (1989) clarified a persuasive claim that pictures may assist both teachers and learners, since it offers inspiration and to encourage learners to use their imagination in speaking and writing [7]. Here are several experts' arguements of picture-cued as instructional media can enhance learners' writing capability. First, series of pictures can be maintained as they are used to contextualize a story or description of a process (wright, 1989, p. 201). Second, pictures can be used to assist learners to enlarge details, thought, or series of story. Third, Gregoria, et. al. (2015) clarifies that picturescued series utilized is a precise strategy for EFL learners in acquiring writing skills. Then, Febriani (2014) adds that picture-cued series initiate a innovative atmosphere for learners in writing class [8]. In short, can be summed up pictures pose numerous roles in English acquisition, which arouse learners to partake in classroom actions, grasp learners' attention and interest, provide them a variety of tasks, arouse them to learn English, particularly learning writing skills, etc [9].

SMKN 4 is one of Government's favorite schools at Pontianak, in Kal-Bar. It was dominated by boys last time, then now it is opened for girls too. There are 14 programs are offered such as, Computer Network Engineering, Industrial Electrical Engineering, Audio Video Engineering, Spatial Cooling Technique, Electrical Installation, Laboratory Test Analysis, Welding Technique, Mechanical Engineering, Geomatics Engineering, Motorcycle Business Engineering, Technical Light Vehicle, Maintenance Sanitation Building Construction Engineering, Drawing technique, and Property Construction Business Engineering. The numbers of the programs are added in accordance with the demands of society, also job opportunity offered. The Vocational School is vocational high school, abbreviated as SMK, is a formal education at the secondary education level that organizes vocational programs and as the continuation of Junior High school and its levels [10]. SMK is part of the national education system which has a vocational education goal, namely, to produce workforce skilled who has the ability in accordance with the demands of the business needs or industrial world, as well as being able to develop their potential in adopting and adapting to the development of science knowledge, technology and art [11].

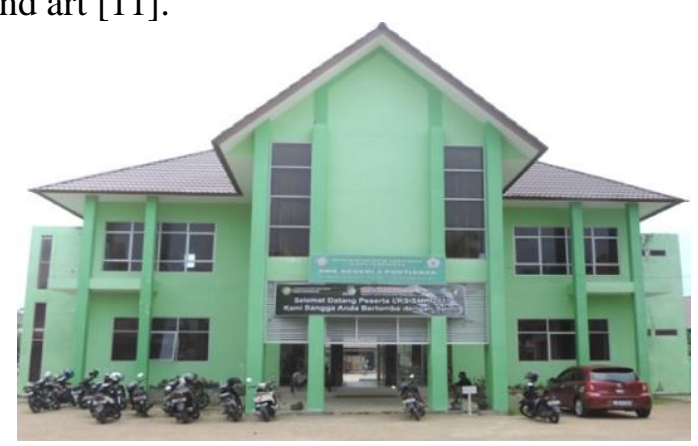

Figure 1: SMKN 4 Pontianak, Kal-Bar.

Here is the picture of SMKN 4 Pontianak. It is located on Komyos Soedarso Street, with large area of the school. It is a strategy school that far from the crowded for the effective teaching learning process. 


\section{IMPLEMENTATION METHOD}

This community engagement (PKM) workshop conducts as the lecturers' task to fulfil the lecturers' duty for the university. As we know there are three duties must be fulfilled by lecturers for the university, first, to do the teaching learning process; second, to do the community engagement activity; third, to do research. So this community engagement is one of leturer's duties to university. Of course this community engagement has the main point, that is to contribute for the innovation in pedagogical field. Next, this community engagement can be done after getting the approval from the school principal that already have the memorandum of understanding (MOU) with STMIK Pontianak, the home-based of the lecturer who did the community services. Actually there are some schools already have the memorandum of understanding with STMIK Pontianak, and SMKN 4 is one of the schools. This MOU made for the mutual benefit of both side, especially in educational part. Previously, some visits to this school already conducted, especially to see the school's principal for some advices then ask permission for this community engagement workshop held at SMKN 4 Pontinak. Mr. Syahri, ST., MT. is the principal of SMKN 4 Pontianak in this periode. He is a wise and kind person. We are welcomed friendly by him and the school staff. Some advices, suggestions delivered by him for the good of this workshop. In accordance with the agreement then this activity done smoothly. It is done at SMKN 4 Pontianak, located on Komyos Soedarso street, on Thursday $15^{\text {th }}$ February 2020 in Pontianak. It is as one of favourite Vocational Government School in Pontianak, because of the programs offered. Next, the lecturer gets the letter addressed to SMKN 4 from LPPM of STMIK Pontianak as the letter of assignment, besides the proposal to do the community engagement workshop at SMKN 4 Pontianak. It is a workshop, attended by 32 learners of SMKN 4 Pontianak. Here are the activity listed done:

a. Introduction: The lecturer introduces herself to the class, her name, where does she from, what does she do, the subject handled, and the purpose to visit the class.

b. The lecturer tries to know the students more close by having the students list of their names. Next,

c. Introduce English as the subject to be discussed, the English language skills at glance, and the hindrances often come across by learners, especially writing skill.

d. Have the students to write something on a piece of paper with vary topics, for their writing competence.

e. Have students to identify their writing obstacles encountered while writing. Students' hindrances in writing are: no ideas to be elaborated, incorrect grammar, limited vocabulary, tenses, and the coherency.

f. Lecturer tries to familiarize Picture-Cued technique with some writing activities to assist learners with writing obstacles come across.

g. Some students are pointed to make sentences based on the situation of picture-cued displayed on the board.

h. Students are guided and helped while writing using picture-cued technique applied step by step.

\section{RESULT}

This workshop done on Thursday, $15^{\text {th }}$ of February 2020. It can be held after the permission and agreement also the MOU between STMIK and SMKN 4. After all the administrations, including the assignment letter and the proposal completed then the workshop can be conducted. Based on the procedure above after the introduction section then learners are asked to write sentences or paragraphs of their own knowledge of English with vary topics without any helped from lecturer. Students get difficulties in choosing and expressing the topics, and do not know what to write. They do look confused and some did nothing. Almost half of the class wrote nothing in the paper collected. When the time of writing over then all students' papers are submitted then checked by the lecturer. Students are asked to identify what are their 
problems in writing. As stated above the writing obstacles are no ideas to be elaborated, incorrect grammar, limited vocabulary, tenses, also the coherency.

Lecturer tries to identify obstacles come across in writing by learners. Lecturer gives explanation and the ease of how to minimalize the writing hindrances. Lecturer tries to familiarize Picture-Cued as one of teaching writing technique. This technique applying pictures to generate learners' ideas. As we know there are three activities of Picture-Cued technique, those are Short Sentence Type, Picture Descriptive Type, and Picture Sequence Descriptive Type. This is a kind of intensive (controlled) writing used in EFL classroom, which pictures cued tasks, students are asked to make [12]:

a. Short sentences

b. Make picture description to the picture cued displayed on the screen using prepositions such as; on, in, at, in front of, next to, beside, etc, then,

c. Picture sequence description, where students write pictures chronologically.

All the activities are displayed with vary pictures, vocabularies and also questions as guidance in writing. In Short Sentence Type, as elaborated below, the guided questions are attached to assist learners in correctly grammar created and building the ideas. From the questions attached shows the use of singular (is) and plural linking verbs (are), also the use of present continuous tense. Learners are taught to be able to distinguish the singular question to plural questions. As well as assisted in making simple and short sentences based on the pictures, vocabularies, and questions. There are 5 pictures provided with varies picture backgrounds also singular and plurals backgrounds. In short, in first activity of Picture-Cued Technique learners are taught to make simple and short sentences using of linking verbs, using of present continuous tense, familiarized to new vocabularies, and to be able to distinguish between singular and plural objects or items also the sentence pattern. Teacher guided are needed to assist and guide them in making simple or short sentences to the pictures shown. Besides, the discussions between learners are allowed and suggested in making sentences.

In Picture Descriptive Type or the second activity of Picture-Cued technique, pictures are displayed with some objects in one picture to teach learners with the use of preposition in, on, under, beside, in front of, behind, next to, and above. By having this activity it guides learners to make sentences with the positions of objects precisely. Then they have to make sentences, next join the sentences to be a paragraph. The vocabularies also attached to assist learners with unfamiliar items in making sentences. Learners are assisted in making sentences with the use of prepositions, as well as the sentence pattern also taught as in Short sentence Type.

At last activity of Picture-Cued technique, that is in Picture Sequence Description Type. This is rather hard part for learners, but pictures and the list of vocabularies are still provided to guide learners to the picture sequence description. In this type of Picture-Cued technique learners are guided with the sequence of pictures of the activities done. They have to think deeply and logically of the sequence pictures of activities, which one is the first, the next, and the last. There are vary and many of sequence of pictures of activities can be provided to arouse learners' ways of thinking logically. The pictures of washing car sequence cards and picture of ready to school sequence are provided in this type. It's rather hard part since there are two activities simultaneously must be completed by learners. First, they have to arrange the correct picture of a sequence of series activities then they have to write or describe the pictures about. That is why this is rather complex part to finish by them.

These are the class situation of SMKN 4 Pontianak delineated in figure 2 and figure 3. It has large classroom enough for 32 students, with some windows at the back, and one door in front of the class with enough lighting too. They are nice and welcome the lecturer for the workshop. There are 32 students, 15 girls and 17 boys who attend the community engagement workshop. They are really enthusiatic in listening to the explanation from the lecturer about picture-cued technique applied in teaching writing. Many questions are asked by them to show their willingness to the teaching technique familiarized to them. Some of the questions are : Are there some other pictures for different situations ? ; How to create correct sentence using 
picture-cued practice? ; Can this technique help us to write easily? ; What does it mean (prepositions)?; Where should we arrange the sentence ?

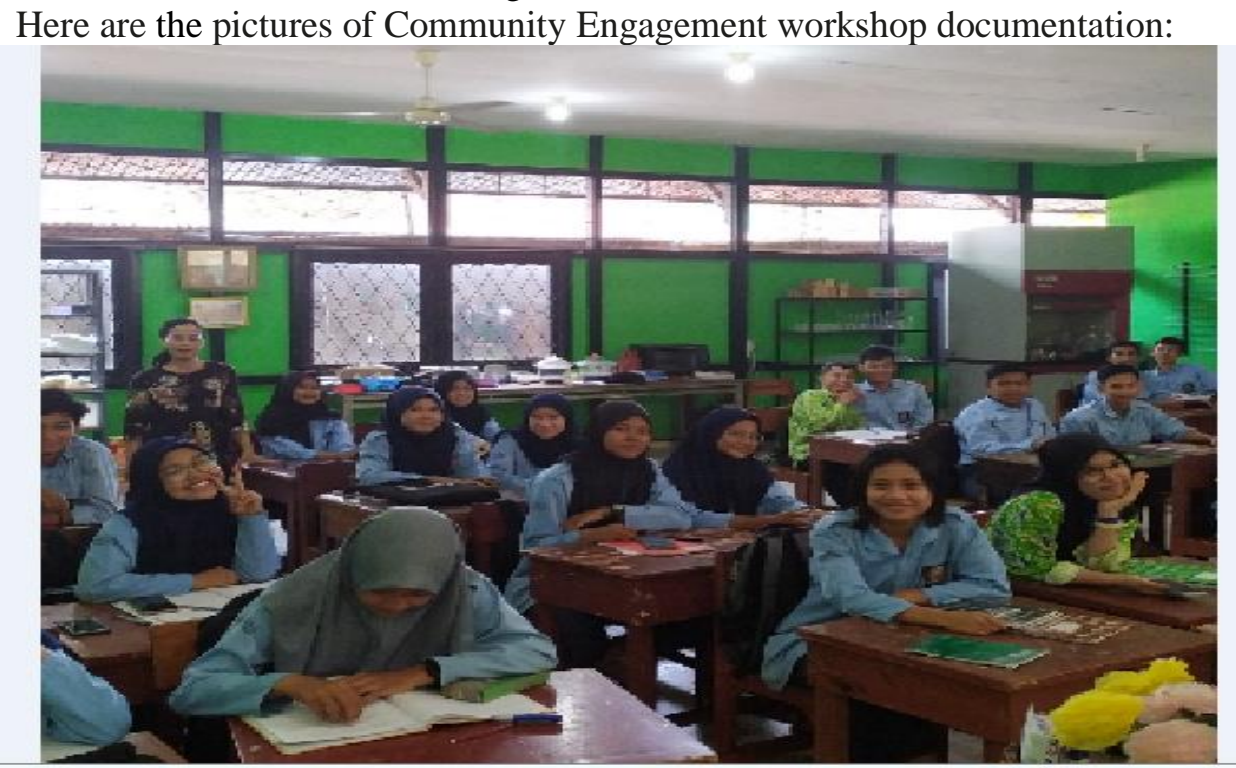

Figure 2 : Classroom Situation of Community Engagement Workshop

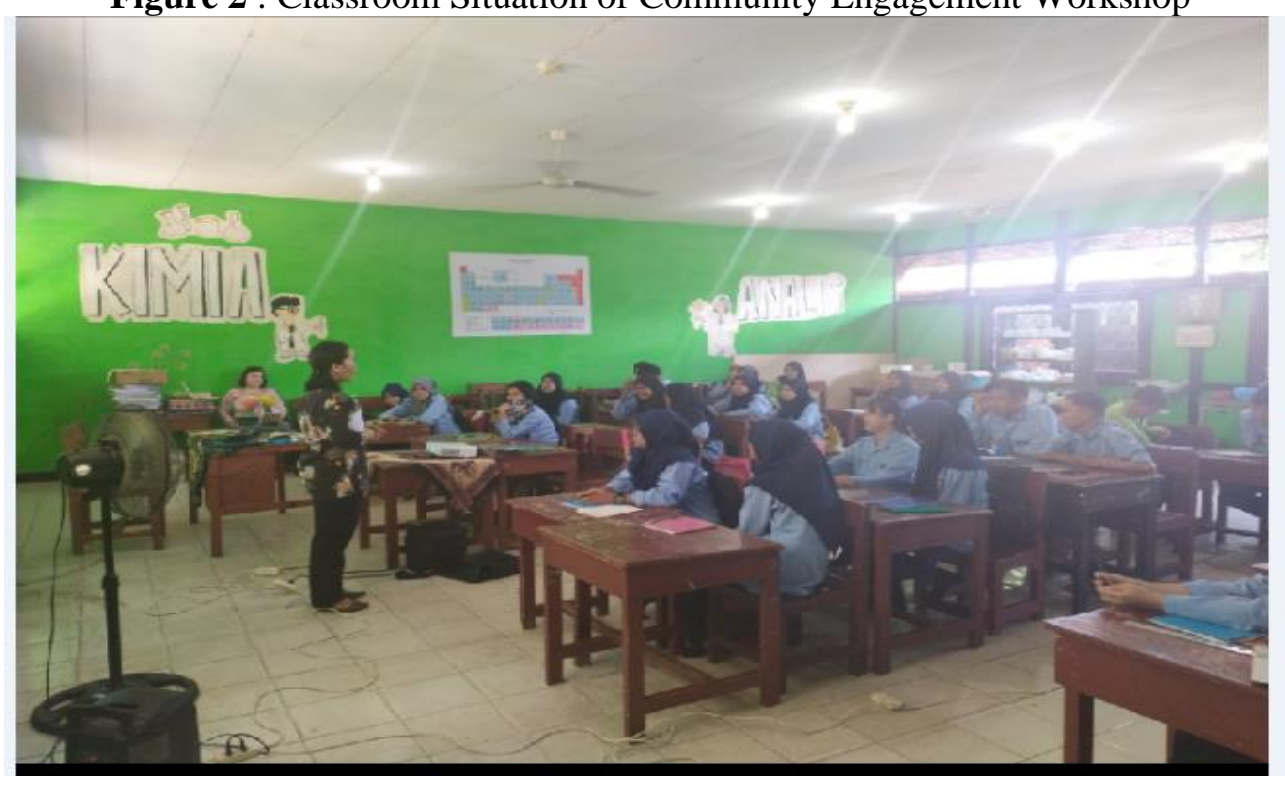

Figure 3 : Classroom Situation of Community Engagement Workshop

There are three activities of Picture-cued technique, those are:

a. Short Sentence Type

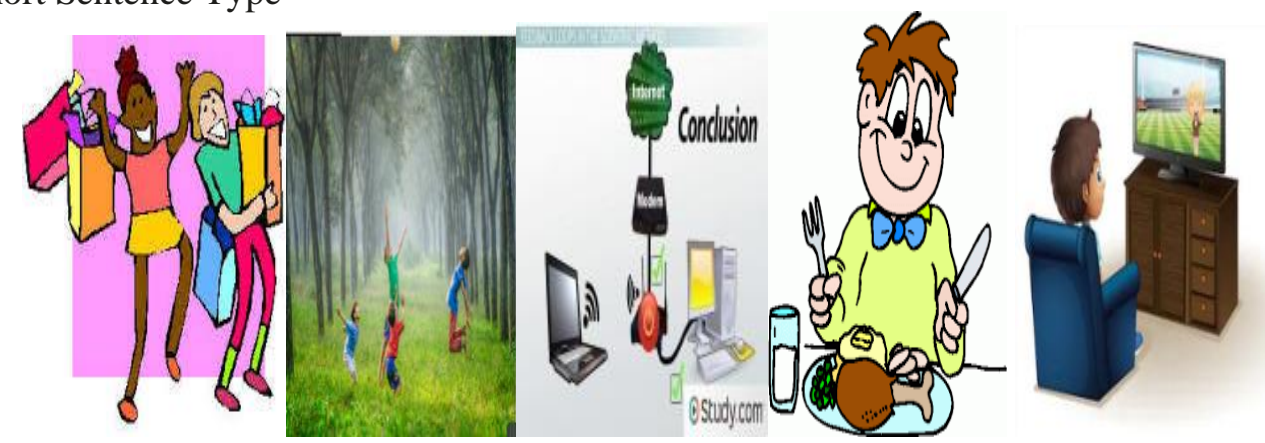

Figure 4: Pictures 
These are some pictures that may lead students to write sentences refer to the images. By looking at these portrays it may inspire learners' ideas to write. The vocabularies and guided questions are also prepared, the questions are as follows:

(Vocabulary: plastic bags, full of items, two happy girls, play ball, at backyard, breakfast, finish office job, have, fried chicken, watch )

a. What are the girls in the first picture carrying?

b. What are the boys doing, and where are they?

c. What can a computer do for you?

d. What is Tom having for his lunch?

e. What is the boy doing?

b. Picture Descriptive Type

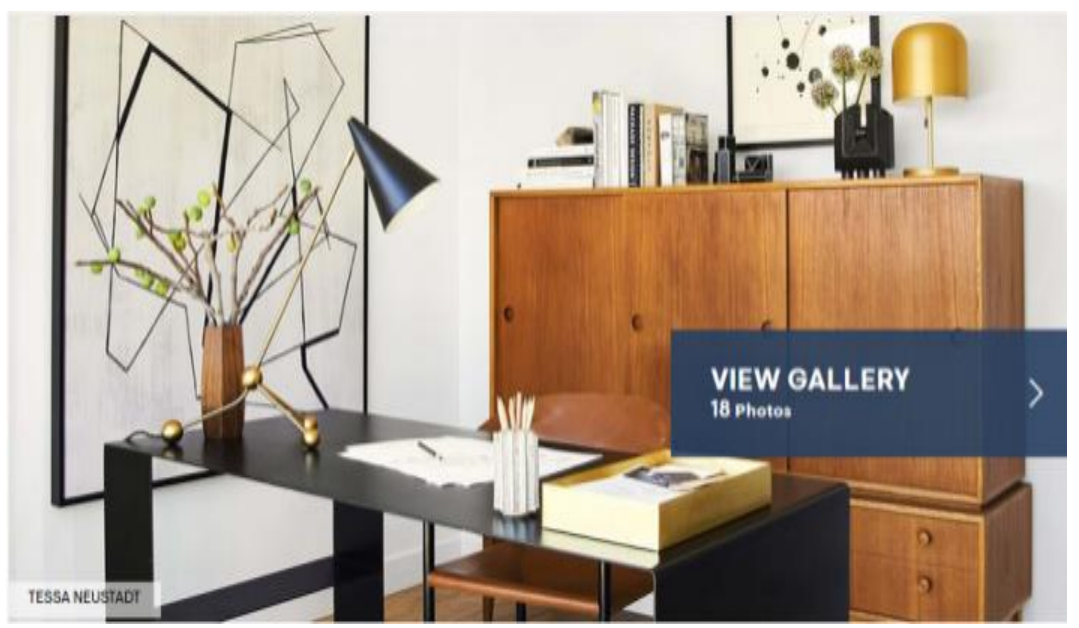

Figure 5: Office Situation

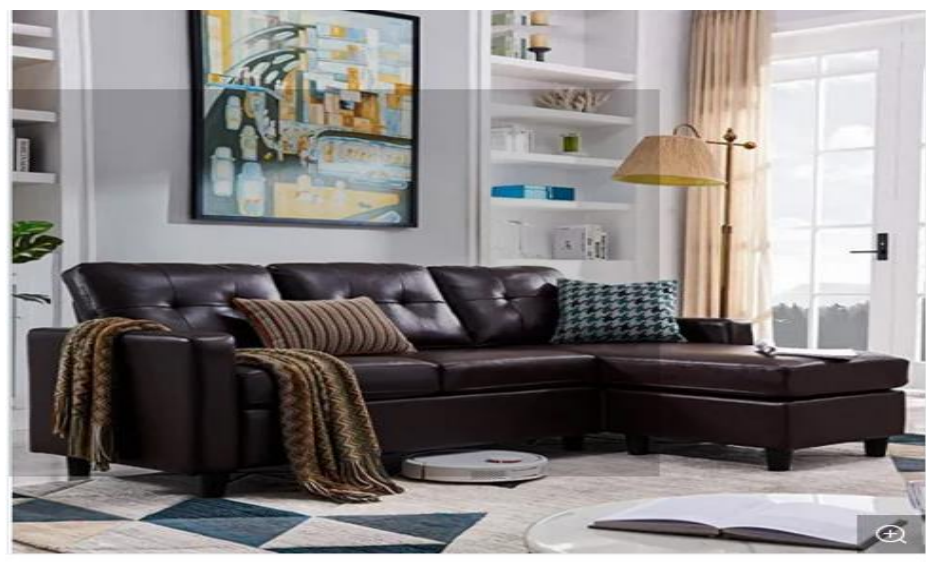

Figure 6: Living room situation

These are the pictures displayed and must be described by learners using prepositions such as, on, in, at, in front of, under, besides, next to, etc. Then all the sentences are joined to be one paragraph. The first is the picture of office situation with all the items in office room. The second is the picture of living room situation with its objects showed. Students have to be able to describe and to posit the objects position precisely. In this second type of Picture -Cued technique it teaches learners with the use of preposition to identify objects location in pictures correctly, besides the correct sentence pattern.

(Vocabulary: in; on; in front of; besides, behind; under; above; office; table; vase; jar; lamp; cupboard; books; papers; wall; chair) 
(Vocabulary: curtain; shelf; pillow; blanket; hanging lamp; door; window; picture; wall; sofa; carpet; floor; flower).

c. Picture Sequence Description Type

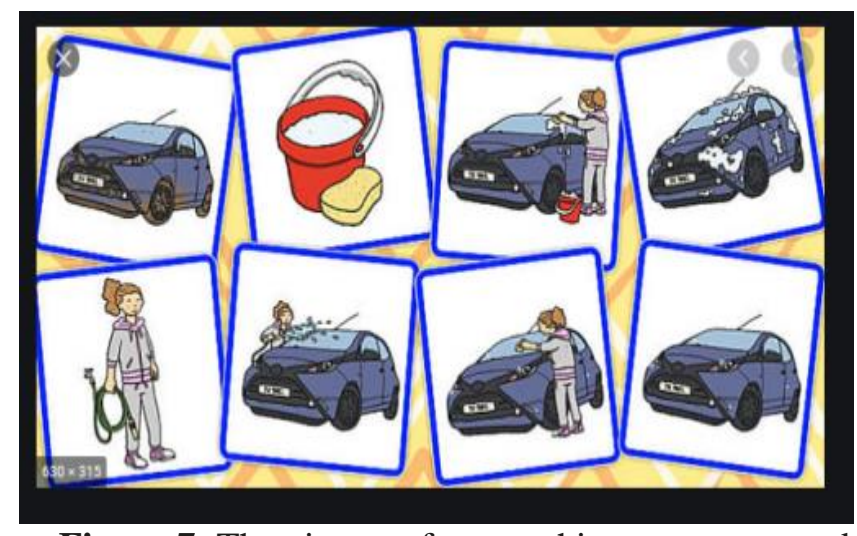

Figure 7: The picture of car washing sequence cards

(Vocabulary: wash; the dirty car; car is clean ; ready; car washer; there is; windows; dirty; clean; water pipe: a pail of water; soap)

(Vocabulary: go to school; wash the face; on foot to school; brush teeth; take a bath; ready; have breakfast; together; wake him up; time to school; mother; father; little bother; accompany )

Ready for School Picture Story Sequence

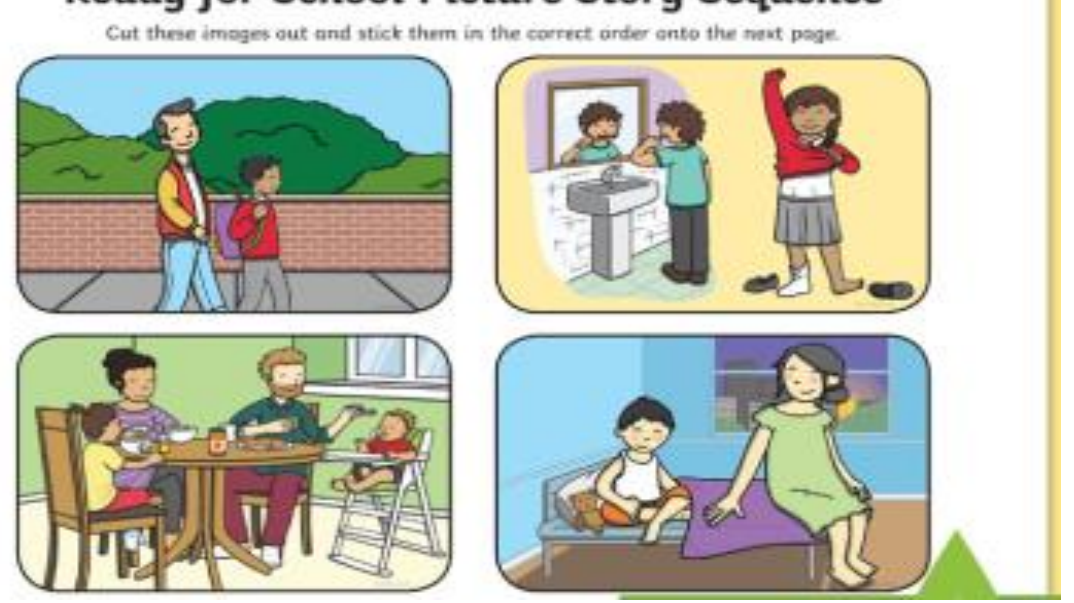

Figure 8: Picture of Ready to School Story Sequence

In this type of intensive (controlled) writing tasks, students are required to rearrange the jumbled picture into the excellent order sequences with the description to the images. The describtions of the images are written by learners. The picture of car washing sequence cards and the picture of ready to school story sequence are displayed to learners to be able to think logically of sequence activities performed, which come first, second, and next. Besides two activities are needed to do simultaneously in one picture, first to arrange the picture, then describe the picture arranged. Pictures and vocabularies also attached in this third activityy of picture - cued practice.

There are various kinds of pictures-cued for learning with different and exciting topics to be explored. In Short Sentence Type, there are five Picture-Cued provided and the questions to be answered as the guidance and to lead the students in writing. They consist of simple questions with daily or routine activities, such as shopping, eating, playing ball, computers, and watching TV. And for its grammar, it discusses using singular and plurals linking verbs, is and 
are, also the sentence pattern. Then in Picture Descriptive Type, students are provided with views of a living room, and an office to be described using prepositions, such as in, on, in front of, under, besides, behind, etc. Students must posit the correct prepositions based on the object's position in the views. Then all the sentences must be joined to become a logical and meaningful paragraph. Next, the last type is the Picture Sequence Description Type. In this type, pictures are in a jumble; students must arrange them into the good and right order with the sentences of the description below the images. The first picture is the car washing sequence cards, and the second picture is a picture of the daily activities before going to school. The sentences of the description must be written by the students. In this type of picture-cued technique, students learn the sequences of events based on the pictures sequence cards provided, which may foster students to think deeply which come first, next, and the last, and describe the pictures.

Having these three types of Picture-Cued technique activities really assists the students of SMKN 4 in the process of writing, which starts from the simple to rather complex tasks of writing the description of pictures, with questions guided and vocabularies attached. And they enjoyed using this technique in learning. They can do this individually or in pairs, they are free to choose their partner. Moreover, grammar, vocabulary, the coherency of the ideas are stressed and discussed in this technique. Indeed, students are assisted using this technique in this workshop. Here are students' writings before the picture-cued technique applied in workshop as shown in picture 9. In this time, students still confused what ideas to describe, lack of proper vocabularies used, grammatically incorrect, besides the coherency of ideas. In picture 9 those are the examples of students writing before the explanation and the assisted of Picture-Cued technique. They wasted of time to think what ideas to be written. They complained," We don't know what ideas to describe, we are confused, we need more time to think, it's difficult, etc. Finally, some papers are blank, nothing to be written by them. In picture 10 those are students writing tasks after picture-cued practice familiarized and practiced together in writing. Of course, this technique is introduced step by step to them from the first until the third activities of Picture-Cued technique. In picture 10 students are already guided with the pictures, vocabulary, and the questions. Thus, student's writings are guided and well arranged. This is effective technique in assisting learners in writing of language. Although not all students can write correctly for the tasks but at least they are assisted with the vocabularies and questions provided, also the pictures. Mistakes are still happened. Some still do not use the linking verb (is and are) in the sentences. Some use the wrong linking verbs, and others still cannot make the sentences. Sentence pattern is still the hindrances for learners too. Anyway, teacher's assistance is also needed in guiding learners in writing.

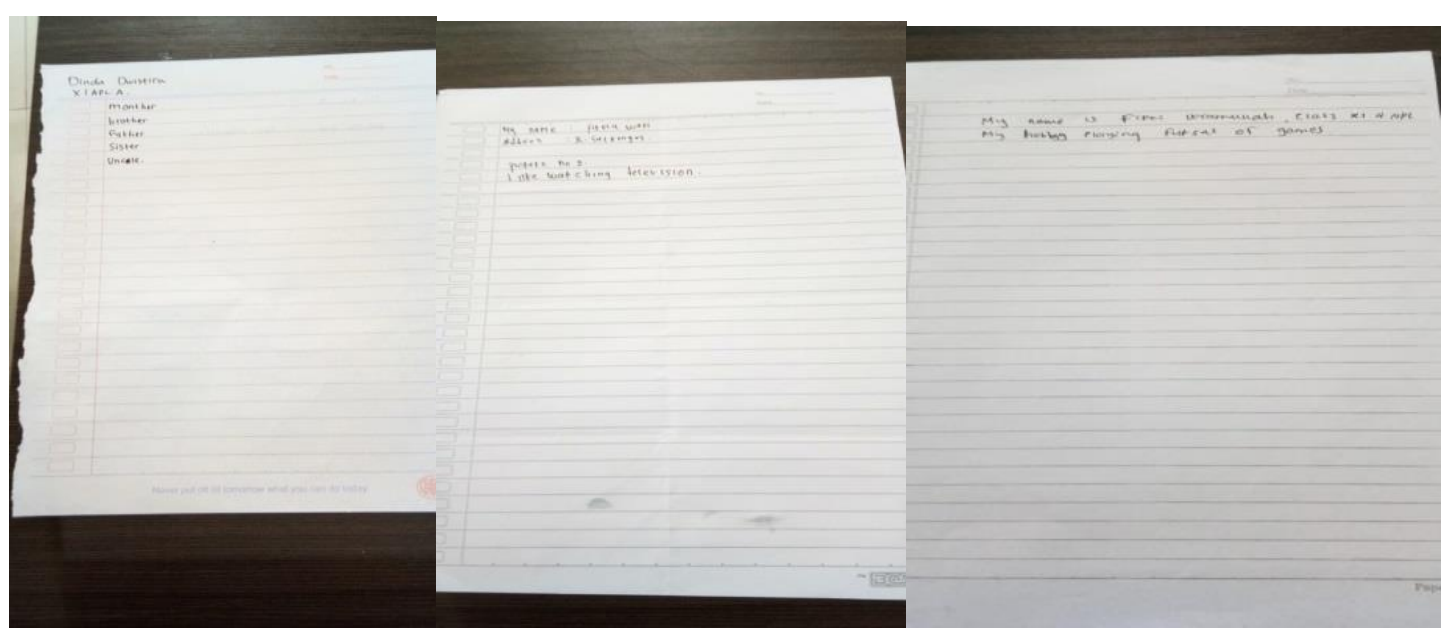

Picture 9: Students writing before the Picture-Cued technique is introduced 


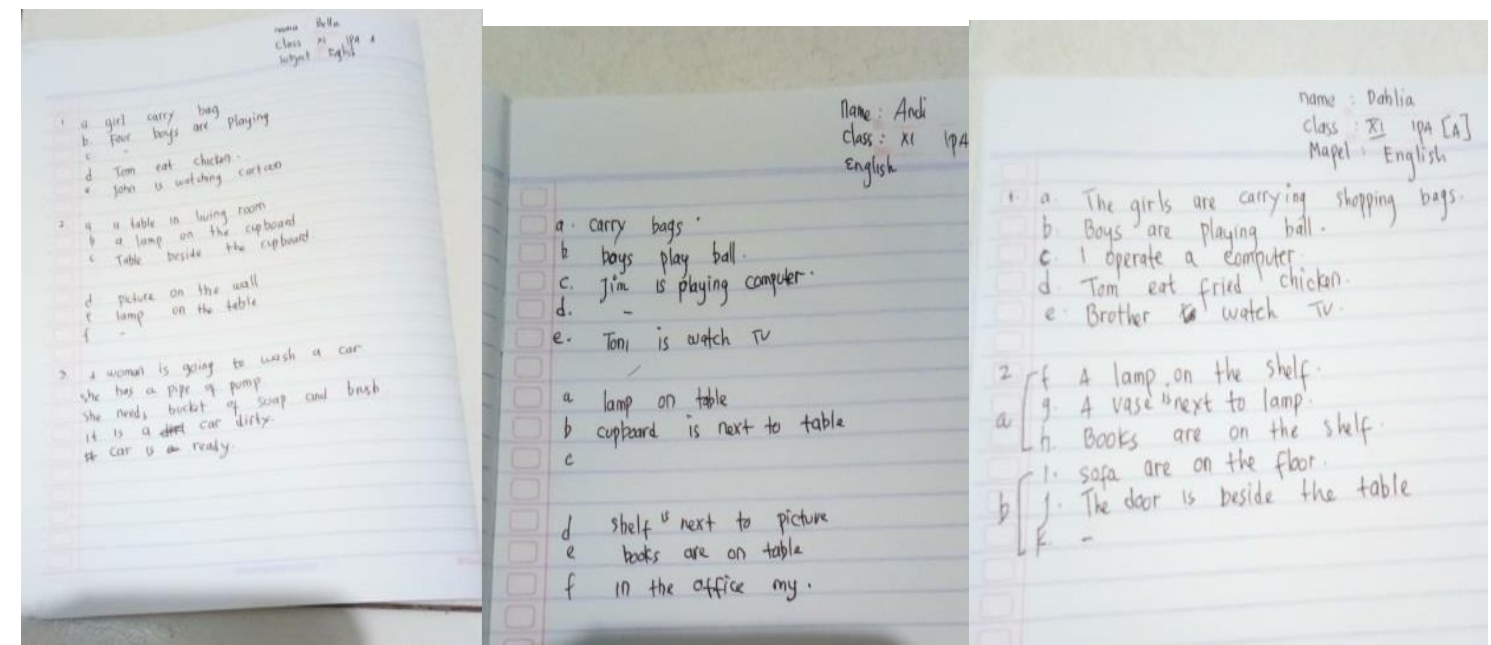

Picture 10: Students writing after the Picture-Cued technique is introduced

\section{CONCLUSION}

As a final point, this community engagement workshop inquiry directed to assist students of the Vocational School of SMKN 4 Pontianak with their writing problems. The Picture-Cued technique is the technique applied in this community services workshop inquiry. It is a technique that may generate, and develop the ideas of writing, besides the writing aspects, such as grammar, vocabulary, the coherency of ideas. Then it can be concluded as an effective technique used to assist and to boost the writing skill of SMKN 4 learners, since it guides the student ways of writing well from the Short Sentence Type, Picture Descriptive Type and Picture Sequence Description Type activities of Picture-Cued technique with vocabularies, pictures also questions attached. It assists learners from very basic knowledge, such as the use of linking verb is and are, singular and plural sentences, the prepositions used in locating the objects, sentence pattern, vocabularies usage, till join some sentences into one coherence paragraph. Indeed learners are assisted in overcoming their writing' hindrances. In short, the picture-cued technique is effective in assisting and improving students' writing skills of the Vocational School of SMKN 4 in the community services workshop

\section{SUGGESTION}

A regular and continuous community service workshop inquiry is recommended and suggested to be conducted by the teachers, lecturers, especially the lecturers of STMIK Pontianak, for the ease and improvement of language learning by EFL learners, particularly for English subject. The longer allocated time of Community Service workshop is needed for the sake of significant outcomes. Hopefully, this Picture-Cued technique applied indeed useful not only in assisting and boosting students' writing skill, but also the other skills of language learning, such as speaking. And this technique can be applied widespread by the educational practitioners to assist students with their writing hindrances in learning foreign or second language. Further research of picture-cued technique is recommanded for the more significant outcomes of learning, specially for writing competence.

\section{REFERENCES}

[1] D. Ariningsih, D. The effectiveness of using picture series to improve the students' writing skill viewed from their learning motivation (An Experimental Study in the Seventh Grade of SMPN 1 Tanjunganom Nganjuk in the Academic Year 2008/2009) (Doctoral dissertation, UNS (Sebelas Maret University)). 2010. 
[2] S. Wagiyo., Suzana. "The Use of Journal Writing in Teaching English Writing," Research Gate, p. 2-3. 2018

[3] Z. A. Aziz, \&. N. Magdalena, "Using a dialogue journal to develop writing skills," English Education Journal, 7(4), 416-432. 2016.

[4] E. Iftanti, "Improving students' writing skills through writing journal articles," Ling. Sci. J. Bhs., vol. 8, no. 1, 2016.

[5] A. S. Yoga. Improving the eighth grade students' writing skills through picture-cued activities at smp n 1 wonosari in the academic year of 2012/2013. p2. 2013

[6] A. Ramadhani. The Implementation Of Picture Sequence Technique In Teaching Procedure Text Writing At The Third Year of SMPN 23 Bandar Lampung. 2017.

[7] P. I. Lavalle., M. Briesmaster. The Study of the Use of Picture Descriptions in Enhancing Communication Skills among the 8th-Grade Students--Learners of English as a Foreign Language. ie: inquiry in education, 9(1), 4. 2017.

[8] K. Khotimah, B. Daud, \& B. Burhansyah. Using Picture Series to enhance students' ability in narrative writing. Research in English and Education Journal, 2(2), 162-169. 2017

[9] Indonesia, "Peraturan pemerintah Republik Indonesia nomor 17 tahun 2010 tentang pengelolaan dan penyelenggaraan pendidikan," Kementerian Pendidikan Nasional, 2010.

[11] Permendikbud No.34, "Tentang Standar Nasional SMK/MAK," 2018.

[12] R. Ahmad, "Assessing Students' Writing Skill Using Picture-Cued for The Students of SMPN 1 Mranggen". 